Goldstein, G. \& MACKAy, I. (1969) The Human Thymus. Heinemann, Medical Books Ltd: London.

GotofF, S.P. (1968) Lymphocytes in congenital immunological deficiency diseases. Clinical and Experimental Immunology, 3, 845.

Hinds, E.A., Linkner, L.M., Cloud, D.T. \& Trump, D.S. (1970) Ectopic thymic tissue of the neck. Journal of Paediatric Surgery, 5, 460.

SPEER, F.D. (1938) Thymic cysts: A report of thymus presenting cysts of three types. New York Medical College. Flower Hospital Bulletin, 1, 142.
WADAS, A. (1934) Thymoma intratracheals. Zentralblatt für allgemeine Pathologie und pathologische Anatomie, 60, 308.

WaKsman, B.H. (1964) Thymus experimentation. New England Journal of Medicine, 270, 1018

WARKANY, J. (1971) Congenital Malformations. 1971 Year Book, Medical Publishers Inc.

Zollinger, R.M. JR, LindeM, M.C., Filler, R.M., Corson, J.M. \& WiLSON, R.E. (1964) Effect of thymectomy on skin homograft survival in children. New England Journal of Medicine, 270, 707.

\title{
Renal failure and suprarenal calcification after secondary haemorrhagic disease in a newborn baby
}

\author{
M. W. MONCRIEFF \\ B.M., B.Ch., M.R.C.P.
}

\author{
H. HARGREAVES \\ M.B., B.Chir. M.R.C.P.
}

\section{Special Care Baby Unit, Nightingale Maternity House, Derby}

\begin{abstract}
Summary
A newborn baby who was severely asphyxiated at birth developed secondary haemorrhagic disease which was treated successfully with intravenous heparin. However, she was later found to have supra-renal calcification, chronic renal insufficiency and hypertension. It is felt that prompt treatment of conditions that predispose to secondary haemorrhagic disease is very important as, once this has occurred, treatment may not prevent permanent damage to vital organs.
\end{abstract}

\section{Introduction}

Secondary haemorrhagic disease of the newborn occurs mainly in association with severe birth asphyxia, hypothermia and rhesus haemolytic disease (Chessells and Wigglesworth, 1970) and often results from disseminated intravascular coagulation (Boyd, 1967). Treatment with heparin (Whaun, Ormson and Oski, 1971) or exchange transfusion (Gross and Melhorn, 1971) has been advocated, but the mortality is $60 \%$ (Whaun et al., 1971). Although fibrin deposits have been found in many organs at autopsy (Boyd, 1967) we have not found reports of permanent damage to organs other than the brain in the survivors (Bryant et al., 1970).

\section{Case report}

This baby girl was born at 42 weeks' gestation after an antepartum haemorrhage by normal vertex delivery in a nearby maternity home and weighed $3.85 \mathrm{~kg}$. She failed to breathe and after $10 \mathrm{~min}$ was treated with positive pressure ventilation via an endotracheal tube, regular respiration being estab- lished at $\mathbf{4 0} \mathrm{min}$. She was then transferred to the Special Care Baby unit. On arrival she was moribund, with no spontaneous movements, apart from shallow respiration, no primitive reflexes and heart rate of $90 / \mathrm{min}$. Sodium bicarbonate was given intravenously and she was nursed in $59 \%$ oxygen. Her heart rate rose to $140 / \mathrm{min}$, respiration improved and some spontaneous movements occurred. Investigations gave the following results: $\mathrm{Hb} 11.7 \mathrm{~g} / 100 \mathrm{ml}$, platelets $103,000 / \mathrm{mm}^{3}$, prothrombin activity $12 \%$, pH 7.29, $\mathrm{PCO}_{2} 38 \mathrm{mmHg}, \mathrm{Po}_{2} 180 \mathrm{mmHg}$, and serum bicarbonate $18 \mathrm{mEq} / 1$. She was given $80 \mathrm{ml}$ of blood and $1 \mathrm{mg}$ of vitamin $\mathrm{K}_{1}$.

The following day her haemoglobin had fallen to $10.6 \mathrm{~g} / 100 \mathrm{ml}$ and she was given a further blood transfusion. Over the next 4 days she had a number of fits which were treated with phenobarbitone. Her general condition improved with increase in activity and the Moro reflex returned, although she could not suck and had marked head retraction and severe hypotonia. Her urine contained a large amount of blood, but was not infected and the kidneys were not enlarged. On the sixth day of life her haemoglobin had fallen to $8.4 \mathrm{~g} / 100 \mathrm{ml}$, platelets to $12,000 / \mathrm{mm}^{3}$, and she bled profusely from a heel prick. A further blood transfusion was given and later that day exchange transfusion with fresh, heparinized blood was carried out. After this her haemoglobin concentration rose to $13.8 \mathrm{~g} / 100 \mathrm{ml}$ and platelets to $115,000 / \mathrm{mm}^{3}$.

However, the next day the haemoglobin and platelet count fell again and fibrin degradation products were detected in the serum. After another 
blood transfusion, she was treated with intravenous heparin which was continued for 4 days. With heparin therapy her platelet count rose rapidly and thereafter remained normal, and the level of fibrin degradation products declined. The course of this part of her illness is illustrated in Fig. 1.

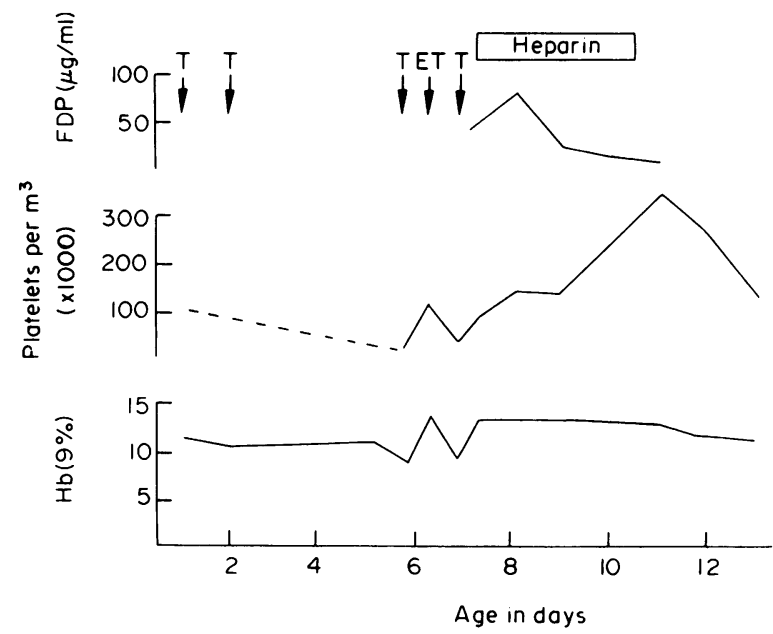

FIG. 1. Haematological findings in the first 2 weeks of life in a baby with secondary haemorrhagic disease. $\mathrm{T}=$ blood transfusion; $\mathrm{ET}=$ exchange transfusion.

At the age of 12 days she had more fits, and her weight had increased by $260 \mathrm{~g}$ in $24 \mathrm{hr}$. Results of investigations were: blood urea $108 \mathrm{mg} / 100 \mathrm{ml}$; serum bicarbonate $12 \mathrm{mEq} / 1$; sodium $100 \mathrm{mEq} / \mathrm{l}$; creatinine $5 \cdot 1 \mathrm{mg} / 100 \mathrm{ml}$. She was treated with normal saline and sodium bicarbonate intravenously, fluid restriction and one injection of frusemide. By the next day her weight had fallen by $100 \mathrm{~g}$, and the serum sodium had risen slightly to $104 \mathrm{mEq} / \mathrm{l}$ and $24 \mathrm{hr}$ later she had lost a further $60 \mathrm{~g}$ and the serum sodium was $145 \mathrm{mEq} / \mathrm{l}$. Thereafter she improved steadily and began bottle feeding. She gained weight satisfactorily on SMA feeds, muscle tone became normal, her blood urea fell to $69 \mathrm{mg} / 100 \mathrm{ml}$ and she was discharged home taking additional sodium bicarbonate.

Radiographs 4 months after birth showed calcification of the suprarenal glands and small irregular kidneys (almost 1 s.d. below the mean for her length) with an area of medullary necrosis in the left kidney. Creatinine clearance a month later was $20 \mathrm{ml} / \mathrm{min} / 1.73 \mathrm{~m}^{2}$ and plasma cortisol, which was $37 \mu \mathrm{g} / 100 \mathrm{ml}$ before an injection of ACTH, rose to $57.5 \mu \mathrm{g} / 100 \mathrm{ml}$ at $30 \mathrm{~min}$ and $70 \mu \mathrm{g} / 100 \mathrm{ml}$ at $90 \mathrm{~min}$. She has gained weight steadily despite a blood urea level of $70 \mathrm{mg} / 100 \mathrm{ml}$. At 8 months of age her psychomotor development was equivalent to 7 months and she had developed hypertension which was treated with bethanidine.

\section{Comment}

This baby had evidence of disseminated intravascular coagulation, bleeding, thrombocytopenia and elevated fibrin degradation products, after severe birth asphyxia and acidosis, known precipitating factors of secondary haemorrhagic disease. Exchange transfusion with fresh heparinized blood, as advocated recently (British Medical Journal, 1971) caused only temporary improvement but after starting heparin therapy there was prompt and sustained resolution of the haematological abnormalities. We feel that in severe cases of secondary haemorrhagic disease where therapy may be needed for several days, heparinization is more efficacious than repreated exchange transfusions.

The low sodium levels found when the baby was having fits at 12 days of age were probably due mainly to overhydration, for she had gained $260 \mathrm{~g}$ in the preceding $24 \mathrm{hr}$, but may also have been due partly to urinary loss of sodium which is known to occur in renal papillary necrosis. Unfortunately urinary sodium was not measured.

The baby survived, but now has supra-renal calcification and chronic renal insufficiency. Though cortisol production is normal at the moment, adrenal failure may occur in later life (Cathro, 1969). The nature of the kidney lesion is not certain. Bilateral renal vein thrombosis is unlikely, as neither kidney was palpable, and recovery is extremely uncommon (Verhagen, Hamilton and Genel, 1965). The radiological appearance in the left kidney suggests that partial medullary necrosis occurred. This causes sodium loss, but not usually massive haematuria, and renal function generally returns to normal (Crispin, 1972). We believe, therefore, that, in addition, widespread glomerular capillary thromboses occurred, as in the haemolytic uraemic syndrome, causing chronic renal insufficiency.

Fibrin deposits are widespread at autopsy in babies who have had secondary haemorrhagic disease and, as Chad et al. (1971) point out, it cannot be assumed that survivors escape unscathed. However, apart from the finding that some babies, who probably had disseminated intravascular coagulation, showed evidence of brain damage (Bryant et al., 1970), we have not found reports of permanent injury in those who have recovered. With better recognition and treatment of this condition the number of survivors will rise and impaired function of vital organs is likely to be detected more often.

We feel that prompt treatment of birth asphyxia and acidosis is important in the prevention of secondary haemorrhagic disease, for once disseminated intravascular coagulation has occurred it may be too late to prevent damage to vital organs. 


\section{Acknowledgments}

We thank Dr R. Whitelaw and Dr A. Crispin for help with interpretation of the radiographs.

\section{References}

British Medical Journal (1971) Leading Article. Haemorrhage in the newborn, iv, 1.

BoyD, J.E. (1967) Disseminated fibrin thromboembolism among neonates dying within $48 \mathrm{hr}$ of birth. Archives of Diseases in Childhood, 42, 401.

Bryant, G.M., Gray, O.P., Fraser, A.J. \& Ackerman, A. (1970) Fate of surviving low birth weight infants with coagulation deficiencies on the first day of life. British Medical Journal, iv, 707.

CATHRo. D.M. (1969) The adrenal cortex and medulla. In: Paediatric Endocrinology (Ed. by D. Hubble), p. 275. Ch. 5. Blackwell Scientific Publications: Oxford.

Chadd, M.A., Elwood, P.C., Grey, O.P. \& MaXworthy, S.M. (1971) Coagulation defects in hypoxic full-term newborn infants. British Medical Journal, iv, 516.
Chessells, J.M. \& Wigglesworth, J.S. (1970) Secondary haemorrhagic disease of the newborn. Archives of Diseases in Childhood, 45, 539.

CrisPIN, A. (1972) Medullary necrosis in infancy. British Medical Bulletin, 28, 233.

Gross, S. \& MelhorN, D.K. (1971) Exchange transfusion with citrated whole blood for disseminated intravascular coagulation. Journal of Pediatrics, 78, 415.

Verhagen, A.D., Hamilton, J.P. \& Genel, M. (1965) Renal vein thrombosis in infants. Archives of Diseases in Childhood, 40, 215.

Whaun, J.M., Ormson, J. \& Oski, F.A. (1971) One year's experience with disseminated intravascular coagulation in a children's hospital. Programme American Pediatric Society, p. 6. Quoted by F. A. Oski \& J. L. Naiman, 1972, Hematologic Problems in the Newborn (Ed. by A. J. Scheffer). Second edition, ch. 8, p. 286. Saunders: Philadelphia.

\section{The treatment of priapism by corpus-saphenous by-pass}

\author{
R. J. E. FolEY* \\ F.R.C.S.
}

\author{
L. R. DE JODE \\ M.S., F.R.C.S.
}

Whipps Cross Hospital, Leytonstone, London

\section{Summary}

Two cases of priapism treated by corpus-saphenous by-pass are presented. Priapism responded to treatment successfully in both cases. Satisfactory erection and sexual intercourse followed 6 weeks after operation in one case. The second patient failed to have further erections. It was thought that this was due to the length of time ( 6 weeks) between onset of priapism and operation.

\section{Introduction}

Priapism is a pathologically prolonged erection not associated with sexual desire and usually painful. Priapism is due either to increased neurogenic stimulation or more usually clotting in the corpora cavernosa and prostatic plexus and obstruction of the venous outflow of the penis (Hinman, 1960). Thus in 1964 Grayhack et al. devised a method of diverting the venous outflow via a long saphenous shunt to the femoral vein. As the corpora cavernosa communicate distally with each other a unilateral shunt is usually sufficient. In this paper, two cases of priapism treated by corpus saphenous by-pass are presented.

* Present address: The Royal Free Hospital, Pond Street, Hampstead, London NW3.

\section{Case reports}

Case 1. A 31-year-old Negro was admitted to hospital with a 36-hr history of priapism. For 2 weeks before admission he had had prolonged erections on waking in the morning. Thirty-six hours before admission he had indulged in prolonged sexual intercourse with his wife. Since then his penis had been painful and erect. He had had a similar episode 7 years previously when he had had an erection for 1 day. This had resolved spontaneously.

Examination revealed a well built Negro with a temperature of $100^{\circ} \mathrm{F}$. His penis was turgid, erect and very hard and measured some 8 in. He had a tender, palpable lymph node in the left groin. Investigation revealed $\mathrm{Hb} 68 \%$; WBC 6000 with a normal differential; ESR $135 \mathrm{~mm} / \mathrm{hr}$. Sickle test was negative.

$\mathrm{He}$ was initially treated with streptokinase $1,200,000$ units i.v. as a loading dose and 6000 units 6-hourly for $24 \mathrm{hr}$. His penis remained erect. Right corpus cavernosum by-pass was then performed. At the end of the procedure the penis was softer and 1 in shorter. During the first $48 \mathrm{hr}$ of the postoperative period the penis was compressed intermittently, using a child's sphygmomanometer cuff. During the ensuing period his penis became smaller and softer still, and his temperature and ESR 